This item was submitted to Loughborough's Research Repository by the author.

Items in Figshare are protected by copyright, with all rights reserved, unless otherwise indicated.

\title{
The impact of the projected changes in temperature on heating and cooling
} requirements in buildings in Dhaka, Bangladesh

PLEASE CITE THE PUBLISHED VERSION

http://dx.doi.org/10.1016/j.apenergy.2011.05.024

PUBLISHER

(C) Elsevier

VERSION

AM (Accepted Manuscript)

LICENCE

CC BY-NC-ND 4.0

\section{REPOSITORY RECORD}

Mourshed, Monjur. 2019. "The Impact of the Projected Changes in Temperature on Heating and Cooling Requirements in Buildings in Dhaka, Bangladesh". figshare. https://hdl.handle.net/2134/9714. 
This item was submitted to Loughborough's Institutional Repository (https://dspace.lboro.ac.uk/) by the author and is made available under the following Creative Commons Licence conditions.

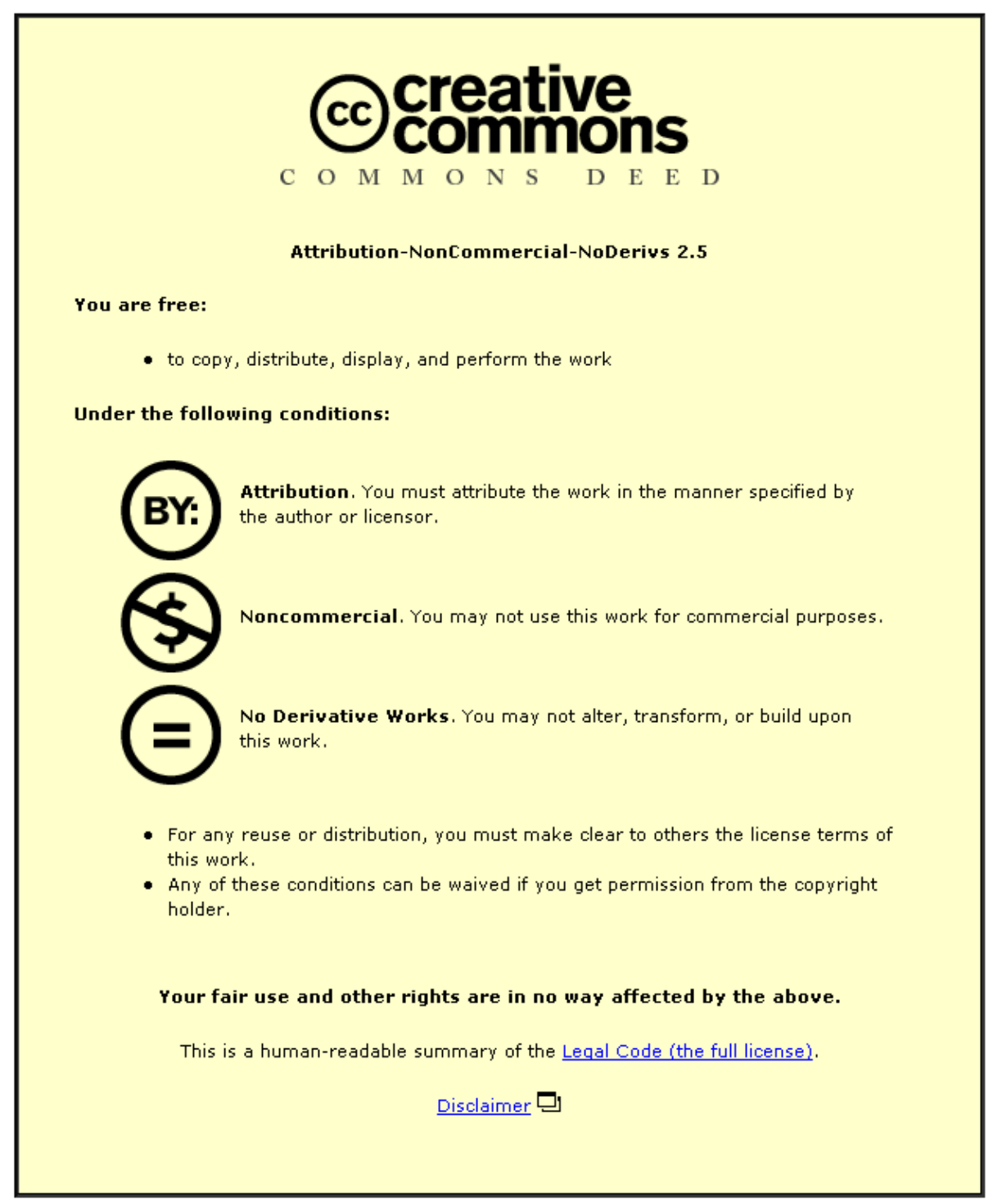

For the full text of this licence, please go to: http://creativecommons.org/licenses/by-nc-nd/2.5/ 


\title{
The impact of the projected changes in temperature on heating and cooling requirements in buildings in Dhaka, Bangladesh
}

\author{
Monjur Mourshed ${ }^{\mathrm{a}, *}$ \\ ${ }^{a}$ Department of Civil and Building Engineering, Loughborough University, Loughborough, Leicestershire, LE11 3TU, United Kingdom
}

\begin{abstract}
Dhaka, the capital of Bangladesh, is a fast growing megacity with a population of 12.8 million. Due to its tropical location, dense urban morphology and higher than average density of population, buildings in Dhaka are likely to be adversely affected by the projected changes in climate, in particular by the increases in temperature. Buildings play a vital role in most aspects of our lives and their energy consumption patterns affect climate change mitigation and adaptation strategies. It is important to understand the likely impact of the projected increases in temperature on cooling and heating requirements in buildings in future climates. In this research, global projections on changes in temperature are temporally downscaled using a statistically averaged baseline present-day hourly weather data to generate future weather data in three timeslices: 2020s, 2050s and 2080s. Time series data for the present-day and future climates are analyzed as well as heating and cooling degree-days are calculated.

Analysis shows that heating degree-days decrease whereas cooling degree-days continue to increase in future climates. The magnitude of change in monthly cooling degree-days is uneven and is greater in winter months than in summer and monsoon. Increased occurrences of temperatures above comfort threshold throughout the year are likely to have significant consequences for human health and wellbeing. The severity and duration of outdoor temperatures in the form of increased cooling degree-days in future climates will result in a surge in demand for energy for comfort cooling, which will add further stress to the already stressed energy infrastructure in the country. Prompt actions from stakeholders are, therefore, essential to enhance the resilience of Dhaka's buildings to climate change.
\end{abstract}

Keywords: Climate change, buildings, Dhaka, Bangladesh, weather data, degree-days, heating, cooling

\section{Introduction}

Bangladesh is cited as one of the countries most vulnerable to anthropogenic climate change [1] despite being responsible for only $0.15 \%$ of global $\mathrm{CO}_{2}$ emissions [2]. The flat and low-lying topography with high population density makes it particularly vulnerable to the impacts of climate change such as sea level changes and increased occurrences of floods and extreme weather events. The projected magnitudes of these impacts appear to be substantial in the case of Bangladesh [3] and have the potential to threaten the very existence of a large percentage of population, either by causing death and damage $[1,4]$ or by affecting livelihoods [5]. Evidence suggests that the government and development stakeholders are aware of the high magnitude climate change impacts and to some extent the means to adapt to these impacts $[6,7]$. The development of policies and strategies to tackle the impacts of climate change has focussed only on the rapid and instantaneous disasters such as floods and extreme weather events that

\footnotetext{
* Corresponding author

Email address: m.m.mourshed@lboro.ac.uk (Monjur Mourshed)
}

can cause visible disruptions to socio-economic systems. Long term gradual changes in climate such as increases in temperature and their impact on buildings and associated systems have not yet been prioritized or emphasized in the policies. One of the reasons behind this is the lack of research based evidence, which this research seeks to address.

The built environment is an important factor in understanding the cause and impacts of climate change. Buildings account for approximately $40 \%$ of global energy consumption and corresponding carbon emissions [8], the release of which in the atmosphere is the primary reason for anthropogenic climate change. On the other hand, changes in climate will impact on buildings, which in turn will affect the occupants. Understanding how buildings behave in the present-day and future climates is, therefore, key to reducing anthropogenic carbon emissions as well as to adapt to the inevitable climate change [9]. The first step in assessing a building's behavior in different climates is to understand the nature and magnitude of changes in climate parameters, the projections of which are done through the application of climate modeling techniques at various temporal and spatial resolutions. The underlying science of 
climate modeling has advanced over the past years [10] in terms of: the dynamical cores; horizontal and vertical resolutions of models; incorporation of more processes (e.g., the modeling of aerosols, land surface processes, etc.); and improved parameterization of physical processes [3]. However, the outputs from global and regional climate models need to be downscaled further for temporal granularity (hourly) to assess the performance of buildings in future climates.

Dhaka, the capital of Bangladesh, is characterized by a high concentration of people with a dense urban morphology. Its population stood at 12.8 million in 2008 [11], which is projected to increase to 20 million in 2020, making it the third largest city in the world [12]. Rapid urbanization coupled with relatively weak planning control and building regulations resulted in densely constructed buildings with poor thermal and/or ventilation performances, even in reference to the present day climate. The urbanization in Dhaka since the 1970s is illustrated in Figure 1 with the help of two satellite images of the city and surrounding areas - one from 1972 and the other from 2001. Vegetation and wetlands were abundant in 1972, which shrank in size and were almost wholly replaced by roads and buildings by 2001 . The city is surrounded by relatively wide rivers in all sides except in the North. The city could, therefore, grow northwards without incurring additional cost for land and infrastructure development. Weak transport infrastructure meant that there was an undue pressure on land in inner city areas for maximizing the built-up area. The characteristics of dense residential developments in Dhaka have been investigated in a recent article [13], in which the author demonstrated how contemporary mid ( $=6$ stories) to high rise $(<6$ stories) buildings lacked adequate open spaces to allow natural ventilation and lighting in interior spaces. Buildings in Dhaka are, therefore, likely to be adversely affected by any increase in temperature. Increased pressure on land for new buildings to house the influx of migrants from rural areas will worsen the situation.

With regard to climate, Dhaka is characterized by high temperatures, high humidity, heavy rainfall and marked seasonal variations. According to Köppen-Geiger climate classification Dhaka's climate is classified as $A w$ or tropical wet and dry [14]. Overall, there are three main seasons in Bangladesh [4]:

- A hot summer season from March to June. Climate characteristics include high temperatures, a high rate of evaporation and erratic heavy rainfall.

- A hot and humid monsoon season from June to October with heavy rainfall accounting for around two thirds of the annual rainfall.

- A cooler and drier winter season from November to March.
The energy demand from a building is influenced by a large number of variables ranging from weather parameters (e.g., temperature, solar radiation, wind, moisture content of air, etc.) to the characteristics of the building (e.g., envelope, form, shape, materials, construction, etc.), its occupants (e.g., occupancy, activities, etc.) and its systems (e.g., type, performance, control schedules etc.). Analysis methods based on degree-days offer a convenient way to estimate energy demand, as it requires significantly less input processing than full dynamic building simulation, thereby reducing the potential for input errors while improving the transparency of the model [16]. The method also allows the assessment of the impact of the projected temperature increases in future climates on building energy demand; i.e., climate sensitivities, in a manageable way. This is because of the fact that changes in heating and cooling degree-days of a location can act as surrogates for trends in building energy consumption [17].

This research is aimed at investigating the projected changes in Dhaka's temperature in the twenty-first century and how this may affect heating and cooling requirements in buildings. The concept of heating and cooling degree-days is applied. Projections from Intergovernmental Panel on Climate Change (IPCC) models are temporally downscaled using a statistically averaged baseline present-day hourly weather data to generate future weather data in three timeslices: 2020s, 2050s and 2080s. Heating and cooling degree-days are calculated from the generated hourly data to investigate temporal changes in degree-days and the implications these may have on building energy demand.

\section{Methodology}

\subsection{Degree-days}

The concept of degree-days has been widely used to estimate weather related energy consumption and in some cases the corresponding $\mathrm{CO}_{2}$ emissions due to space cooling or heating in buildings at various locations worldwide [18-22]. The estimate can be used for benchmarking a building's expected performance against other buildings of similar characteristics, as well as to set energy budgets or negotiate energy tariffs. The other use of degree-days is the ongoing monitoring and analysis of weather related energy consumption and corresponding $\mathrm{CO}_{2}$ emissions of existing buildings based on historical data [16], which can assist in evaluating a building's performance during operation and identify changes in consumption patterns; provide some building and system characterizations; and to set future energy consumption and emissions targets. The trend of changes in degree-days in future climates is, therefore, indicative of the magnitude of the impact of the projected increases in temperature on buildings. 


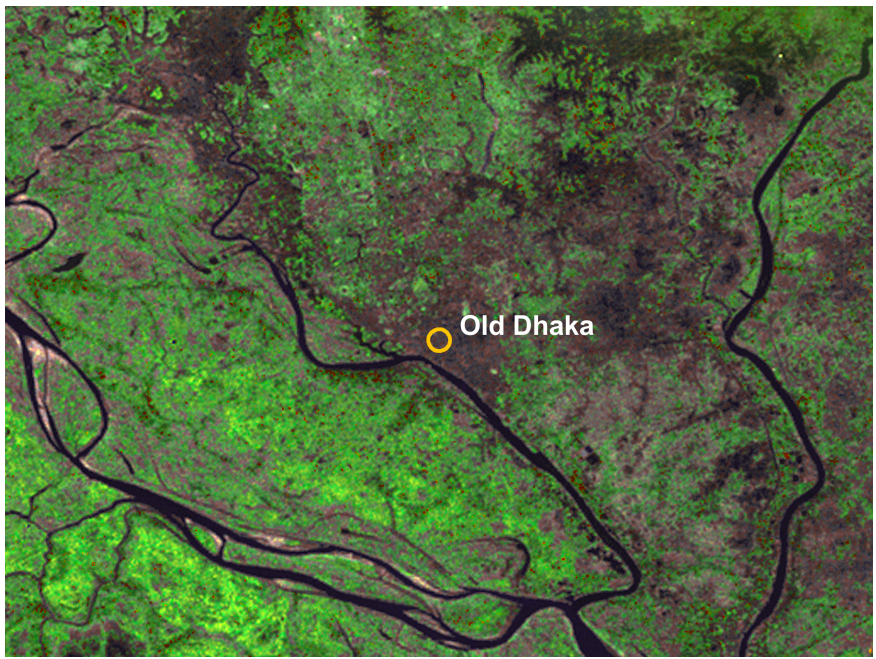

(a) 1972

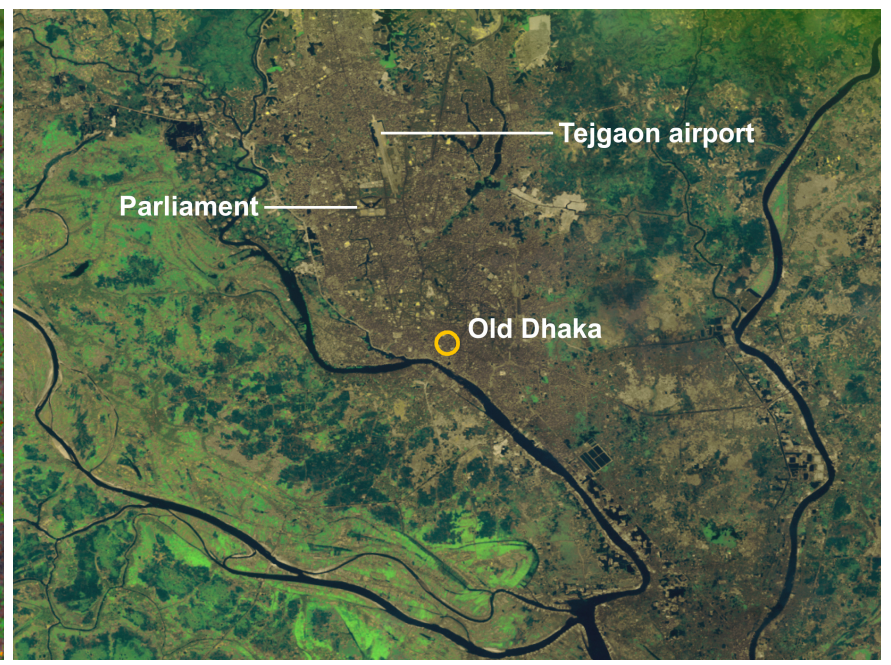

(b) 2001

Figure 1: Satellite images of Dhaka in 1972 and 2001 showing changes in land characteristics, representative of the rapid urbanization during this period: (a) Landsat-1-MSS image on 28 December 1972 and (b) Landsat-7/ETM+ image on 29 January 2001. Source: [15].

\subsubsection{Calculating degree-days}

Degree-days are defined as the summation of temperature differences over time, between a reference temperature and the outdoor air temperature. They capture both the severity and duration of outdoor temperatures. The reference or base temperature is also termed as the balance point temperature; i.e., the outdoor temperature at which the cooling or heating system does not need to run in order to maintain comfort conditions in a building [23]. The heating system needs to operate when the outdoor temperature is below the heating base temperature. The cooling system, on the other hand, operates when the outdoor temperature is above the cooling base temperature. The calculation of heating and cooling degree-days from hourly weather data is given in Equations (1) and (2) respectively. This method is known as the degree-hour or hourly method.

$$
D_{\mathrm{h}, \mathrm{d}}=\frac{\sum_{i=1}^{24}\left(\theta_{\mathrm{b}, \mathrm{h}}-\theta_{\mathrm{o}, i}\right)}{24} \text { for }\left(\theta_{\mathrm{b}, \mathrm{h}}-\theta_{\mathrm{o}, i}\right)>0
$$

where $D_{\mathrm{h}, \mathrm{d}}$ is the daily heating degree-days for one day $\left({ }^{\circ} \mathrm{C}\right.$-day), $\theta_{\mathrm{b}, \mathrm{h}}$ is the heating base temperature $\left({ }^{\circ} \mathrm{C}\right)$ and $\theta_{\mathrm{o}, i}$ is the outdoor air temperature at the $i$-th hour of the day $\left({ }^{\circ} \mathrm{C}\right)$.

$$
D_{\mathrm{c}, \mathrm{d}}=\frac{\sum_{i=1}^{24}\left(\theta_{\mathrm{o}, i}-\theta_{\mathrm{b}, \mathrm{c}}\right)}{24} \text { for }\left(\theta_{\mathrm{o}, i}-\theta_{\mathrm{b}, \mathrm{c}}\right)>0
$$

where $D_{\mathrm{c}, \mathrm{d}}$ is the daily cooling degree-days for one day $\left({ }^{\circ} \mathrm{C}\right.$-day), $\theta_{\mathrm{b}, \mathrm{c}}$ is the cooling base temperature $\left({ }^{\circ} \mathrm{C}\right)$ and $\theta_{\mathrm{o}, i}$ is the outdoor air temperature at the $i$-th hour of the day $\left({ }^{\circ} \mathrm{C}\right)$.
Monthly heating and cooling degree-days, $D_{\mathrm{h}, \mathrm{m}}$ and $D_{\mathrm{c}, \mathrm{m}}$, for a particular month are the sums of daily heating and cooling degree-days over that period. Similarly, annual heating and cooling degree-days, $D_{\mathrm{h}, \mathrm{a}}$ and $D_{\mathrm{c}, \mathrm{a}}$, are the sums of monthly degree-days over the twelve months of the year. In cases where hourly meteorological data are not available, degree-days can be calculated from reduced datasets such as mean daily temperatures or mean monthly temperatures. In fact, the standard method of calculating degree-days varies around the world. In the US, published degree-days are calculated from mean daily temperatures [23]. The UK Meteorological Office (UKMO) publishes degree-days data for UK locations using daily maximum and minimum temperatures [24]. In cases where daily data are not available, monthly mean temperature and standard deviation of temperature can be used to calculate monthly degreedays [25]. The hourly method of calculating degreedays is more accurate than traditional methods. For this reason degree-days are calculated in this research from hourly weather data for the present-day and morphed hourly data for future climates.

\subsubsection{Estimating energy consumption using degree-days}

Since the heat loss from a building is directly proportional to the indoor-to-outdoor temperature difference, the energy consumption of a heated building over a period of time is related to the sum of these temperature differences over the period. The energy demand from heating systems for the heating season or for a particular period (usually a month) can be found from the Equation (3).

$$
F_{\mathrm{h}}=\frac{24 U^{\prime} D_{\mathrm{h}}}{\eta}
$$


where $F_{\mathrm{h}}$ is the energy demand from the heating system for the period considered $(\mathrm{kW} \cdot \mathrm{h}), \eta$ is the overall seasonal heating system efficiency $(-), D_{\mathrm{h}}$ is the heating degree-days for the period under consideration $\left({ }^{\circ} \mathrm{C}\right.$-day) and $U^{\prime}$ is the overall building heat loss coefficient $\left(\mathrm{kW} \cdot \mathrm{K}^{-1}\right)$.

The estimation of energy demand of a cooled building is slightly different from the estimation of heating energy demand. Energy balance of a cooled building has a significant relationship to the fresh air or latent components of the cooling demand. Therefore, a singular heat gain co-efficient, similar to the heat loss coefficient $\left(U^{\prime}\right)$ in the Equation (3), cannot be used. One solution is to estimate energy consumption of the chiller, the calculation of which will vary depending on system type. A discussion on the variation of calculation procedures for various cooling systems can be found in [16, 19]. A generalized method of calculation is given in the Equation (4) to calculate energy demand from the cooling system for a particular period or cooling season by estimating the energy consumption of the chiller.

$$
F_{\mathrm{c}}=\frac{24 \dot{m} c_{\mathrm{p}} D_{\mathrm{c}}}{\operatorname{CoP}}
$$

where $F_{\mathrm{c}}$ is the energy demand from the cooling system for the period considered $(\mathrm{kW} \cdot \mathrm{h}), D_{\mathrm{c}}$ is the cooling degree-days for the period under consideration $\left({ }^{\circ} \mathrm{C} \cdot\right.$ day $)$, $\dot{m}$ is the mass flow rate of air $\left(\mathrm{kg} \cdot \mathrm{s}^{-1}\right), c_{\mathrm{p}}$ is the specific heat of air $\left(\mathrm{kJ} \cdot \mathrm{kg}^{-1} \cdot \mathrm{K}^{-1}\right)$ and $\mathrm{CoP}$ is the average Coefficient of Performance of the plant (-).

\subsubsection{Determining the base temperature}

Traditionally, degree-day data are published at a building base temperature of $15.5^{\circ} \mathrm{C}$ in the UK [16] for 18 regions. Variable base degree-day data have recently been made available for 77 regions, weekly and monthly, at a range of building base temperatures from $10.5^{\circ} \mathrm{C}$ to $20^{\circ} \mathrm{C}$ [26]. In the US, heating and cooling degree-day data are published by the American Society of Heating, Refrigerating and Air-Conditioning Engineers (ASHRAE) at base temperatures $18.3^{\circ} \mathrm{C}$ and $10^{\circ} \mathrm{C}$ respectively [23]. The choice of the base temperature depends on building construction techniques as well as climate variables such as humidity, wind regime, etc. for the particular region [17]. The use of building specific base temperature is, therefore, important for correct energy/degree-days correlations and should take into account the correct (and practical) energy balance of the building [27]. For this reason degree-days are calculated in this research at variable base temperatures ranging from $10^{\circ} \mathrm{C}$ to $20^{\circ} \mathrm{C}$ for heating and $10^{\circ} \mathrm{C}$ to $28^{\circ} \mathrm{C}$ for cooling degree-days at an interval of $0.5^{\circ} \mathrm{C}$. The determination of building specific base temperature is out of scope of this paper; however, discussions on methods such as the use of building performance lines can be found in [16, 27].

\subsection{Construction of weather data for future climates}

\subsubsection{Downscaling}

The projections from global climate models are coarse in terms of spatial and temporal resolutions. For example, the Hadley Centre Coupled Model, version 3 (HadCM3) from UKMO, which is used in the IPCC assessment report [3], has a spatial resolution of $3.75^{\circ} \times$ $2.5^{\circ}$ (longitude-latitude) ${ }^{1}$ and generates monthly change fields as outputs [28]. The outputs need to be temporally and spatially downscaled for use in estimating building energy demand. Belcher et al. [29] developed one such downscaling method called morphing that combines present-day observed weather data with outputs from climate models. The procedure has been shown to yield weather time series that encapsulates the average weather conditions of future climate scenarios, whilst providing realistic weather sequences. In this method, the present-day design weather data are adjusted by the changes to climate projections by global circulation models (GCM) and regional climate models (RCM). The limitation of such method is that it retains the character and variability of the present-day climate, whereas the future climate may have a different character. However, the generated data have been found to be meteorologically self-consistent and coherent with the current best projections. Examples of the application of the morphing method can be found in [30-32].

\subsubsection{Morphing of weather data}

The underlying methodology for weather data morphing consists of three generic operations depending on the weather parameter to be changed: shift; linear stretch (scaling); and shift and stretch [29].

The shift and stretch operation is used in this research to adjust present-day dry bulb temperature by using IPCC projections for the monthly change of the diurnal mean, minimum and maximum dry bulb temperatures. This enables the integration of predicted variations of the diurnal cycle. In this operation, the present-day weather variable, $x_{0}$ is shifted by adding the projected absolute monthly mean change, $\Delta x_{\mathrm{m}}$, and stretched by the monthly diurnal variation of this parameter, to generate the future-climate weather variable, $x$ [29]:

$$
x=x_{0}+\Delta x_{\mathrm{m}}+a_{\mathrm{m}}\left(x_{0}-\left\langle x_{0}\right\rangle_{\mathrm{m}}\right)
$$

where $\left\langle x_{0}\right\rangle_{\mathrm{m}}$ is the monthly mean related to the presentday weather variable $x_{0}$, and $a_{\mathrm{m}}$ is the ratio of the monthly variances of $x_{0}$ and $\Delta x_{\mathrm{m}}$.

\subsubsection{Data sources}

IPCC has adopted six basic global emissions scenarios, which depend on different assumptions for future

${ }^{1}$ This is the resolution at which model dynamics and physics are solved in the atmospheric component of HadCM3; i.e., the Hadley Centre Atmospheric Model, version 3 (HadAM3). 
economic growth, resource consumption, technology implementation, social equity and global population development [33]. These scenarios essentially represent possible development pathways of human activities and function as a baseline for climate change modeling. The outputs from the IPCC A2 scenario (medium-high emissions) for the corresponding grid for Dhaka [34] have been used in this study. The A2 storyline is described as comprising a heterogenous world where the underlying theme is self-reliance and preservation of local identities [33]. The scenario assumes that fertility patterns across regions converge very slowly, which result in continuously increasing global population. Economic development is considered to be primarily regionally oriented and per capita economic growth and technological change are more fragmented and slower than in other storylines. Baseline weather data; i.e., presentday dry bulb temperature (observed weather data), were obtained from the Solar and Wind Energy Resource Assessment (SWERA) [35] in Typical Meteorological Year (TMY) format. The advantage afforded by the use of the TMY data is the encapsulation of typical weather conditions as these are produced using an objective statistical algorithm to select the most typical month from the long-term record. Comparative discussions on various TMY methodologies can be found in [36, 37].

\section{Results and discussions}

\subsection{Dry bulb temperatures in future climates}

Figure 2 shows the number of hours in a year that a particular temperature occurs; i.e., the frequency distribution of temperatures in the four investigated climates: present-day, 2020s, 2050s and 2080s. The distribution was calculated at an interval width of $1^{\circ} \mathrm{C}$. The distribution of temperature shifts to the right under the investigated future climates, indicating warmer temperatures. This is in line with general projections that the climate is getting warmer [3]. The distributions in the present-day and future climates are similar in pattern; i.e., no significant widening or narrowing of the distribution occurs in future climates. The peak in the distribution that shows the most frequent temperature is about $28^{\circ} \mathrm{C}$ in the present-day climate, which increases to about $29^{\circ} \mathrm{C}, 30^{\circ} \mathrm{C}$ and $31^{\circ} \mathrm{C}$ in the 2020s, 2050s and 2080s, respectively. The number of hours of occurrence of the peak temperature is also increasing, from $1036 \mathrm{hr}$ in the present-day to $1097 \mathrm{hr}$ in the 2080s.

Figure 3 shows daily temperature ranges for the present-day and morphed future climates in the 2020s, 2050 s and 2080s. Although the climates are generally getting warmer throughout the year, the increase in winter temperatures is more than that of the summer temperatures. Diurnal variations are generally greater during winter months (November to March) than summer (March to June) and monsoon (June to October) months

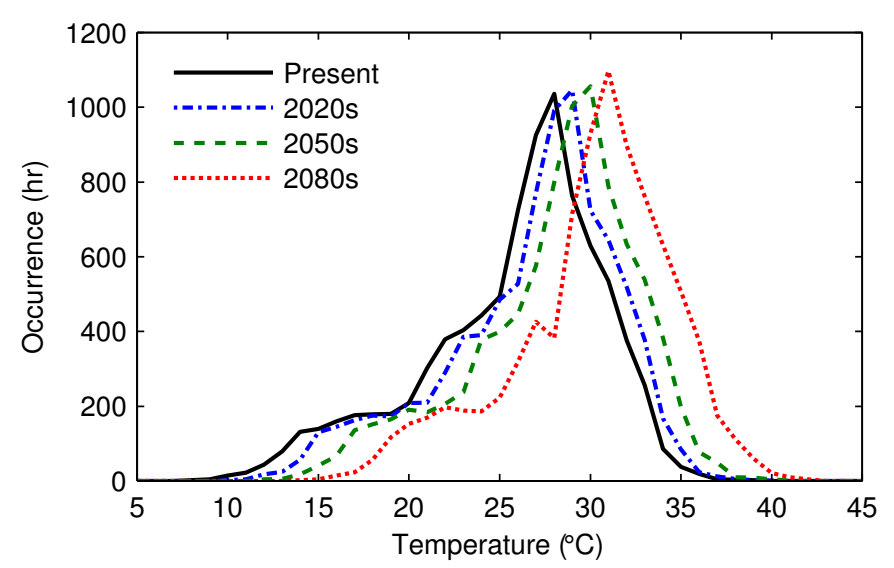

Figure 2: Distribution of hourly temperatures in the present-day and future climates.

in the present-day climate. This meteorological pattern is retained in future climates. However, with the increase in temperature, in particular in the 2080s climate, the length of winter season is shortened. The warming of the winter months are explored further in Figure 4, which shows changes in the daily mean temperature in future climates from the present-day baseline climate. Polynomial curve-fits of the data highlight this trend in different climates with marked seasonal variations. The greatest change of about $30 \%$ occurs in the 2080s in December whereas the greatest change in July is about $11 \%$ for the same climate. Increased winter temperatures in future climates are likely to result in building overheating throughout the year as opposed to during summer and monsoon in the present-day climate. Overheating is explored further in the following section.

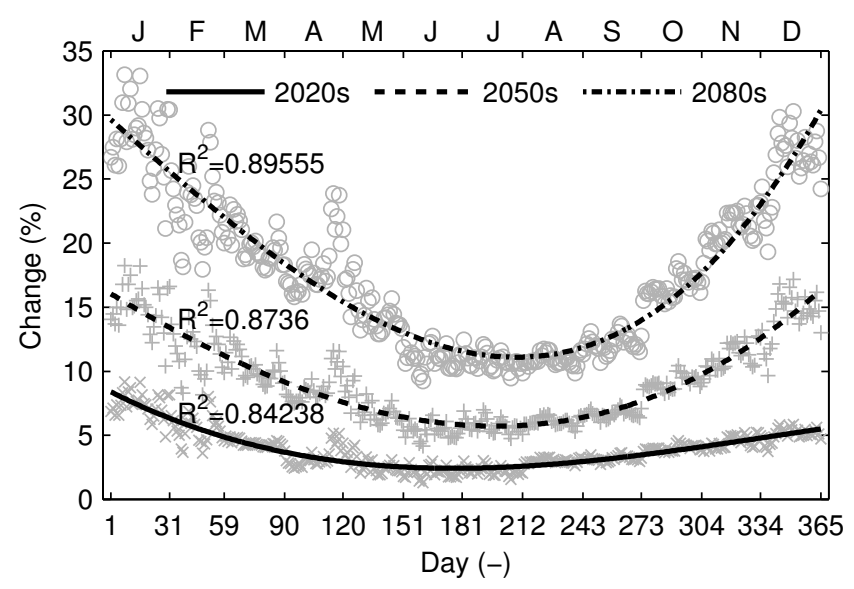

Figure 4: Change in daily mean temperature in future climates along with cubic curve-fits of the data. 

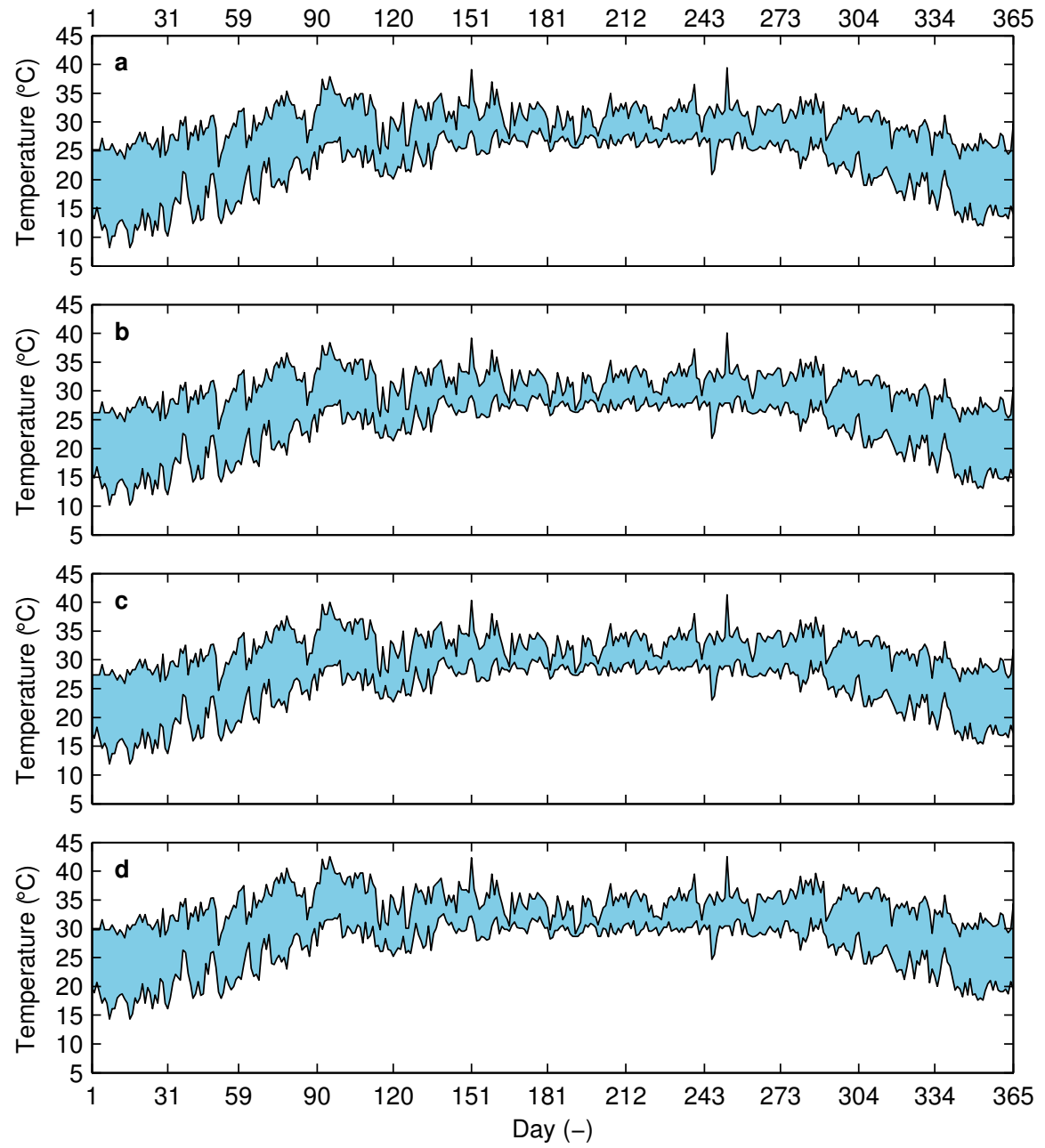

Figure 3: Minimum and maximum daily temperatures in the four investigated climates: (a) present-day, (b) 2020s, (c) 2050s and (d) 2080s.

\subsection{Overheating}

Building overheating is a serious concern for buildings in Dhaka, even in the present-day climate. Most buildings are at risk of overheating throughout the year, apart from the months: January and December. The situation is particularly worse for buildings with high internal gains such as commercial and educational buildings. Majority of the buildings are of solid wall construction without any thermal insulation, which increase solar gain in buildings. Fan-assisted ventilation is the primary means for maintaining comfort conditions in most buildings. However, the installation of refrigerant-based comfort cooling, in particular in commercial buildings, is increasing.

Various approaches have been taken in past research to define overheating criteria [38, 39], which were predominantly based on the definition of acceptable thresholds of thermal comfort conditions. Since temperature is one of the key weather variables that affect thermal comfort, exceedance of certain temperatures for certain durations are usually used as an indicator of overheating. In a previous UK study on overheating [30], the comfort threshold temperatures of $25^{\circ} \mathrm{C}$ and $28^{\circ} \mathrm{C}$ have been used. The criterion used was that internal temperatures should not exceed $25^{\circ} \mathrm{C}$ for more than $5 \%$ of the year and/or exceed $28^{\circ} \mathrm{C}$ for more than $1 \%$ of the year. On the other hand, research [40] indicates that comfort thresholds are higher in tropical humid locations such as Dhaka and tolerance to higher temperatures is above what is typical in cold or temperate climates. However, the thresholds of $25^{\circ} \mathrm{C}$ and $28^{\circ} \mathrm{C}$ are used in this study primarily because internal temperatures are often higher than external temperatures in a naturally ventilated building [38] during occupied hours as internal gains contribute to the rise in indoor temperature.

Figure 5 shows the percentage of time in the year above $20^{\circ} \mathrm{C}$ in the four investigated climates. In the present-day climate, temperatures above $20^{\circ} \mathrm{C}$ occur for about $85 \%$ of the time in the year, rising to about $95 \%$ 
in the 2080s climate. The first overheating threshold temperature, $25^{\circ} \mathrm{C}$, is exceeded for $67.3 \%, 75.1 \%$ and $84.7 \%$ of the time in the year in the present-day, 2020s, 2050 s and 2080s, respectively. The second overheating threshold temperature, $28{ }^{\circ} \mathrm{C}$, is exceeded for $31 \%$, $41.2 \%, 54.3 \%$ and $71.9 \%$ of the time in the year in the present-day, 2020s, 2050s and 2080s, respectively.

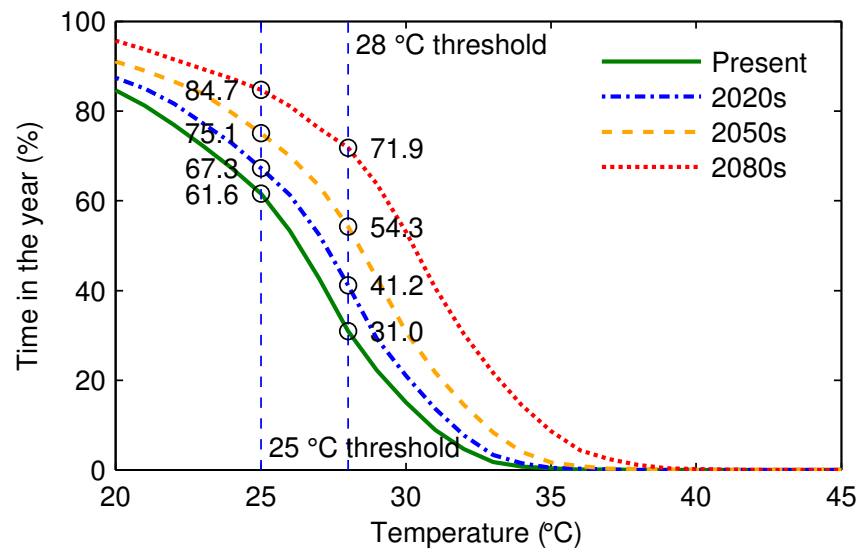

Figure 5: Exceedance of overheating threshold temperatures in the present-day and future climates.

The exceedance of overheating threshold temperatures at this magnitude highlights the fact that the goal of any design and/or refurbishment of buildings in Dhaka could first be to minimize internal and solar heat gains. Natural ventilation or even fan-assisted mechanical ventilation may not be adequate for comfort cooling and ventilation for majority of the buildings with moderate to high internal gains.

\subsection{Degree-days}

The present-day climate of Dhaka is characterized by high temperatures; hence the cumulative heating degree-days for this location is significantly less than the cumulative cooling degree-days. Annual heating degree-days, $D_{\mathrm{h}, \mathrm{a}}$, at various heating base temperature, $\theta_{\mathrm{b}, \mathrm{h}}$, for the present-day, 2020s, 2050s and 2080s are given in Table 1. At the widely used $\theta_{\mathrm{b}, \mathrm{h}}=15.5^{\circ} \mathrm{C}, D_{\mathrm{h}, \mathrm{a}}$ is $34^{\circ} \mathrm{C}$-day for the present-day and is reduced to $13^{\circ} \mathrm{C}$ day, $3^{\circ} \mathrm{C}$-day and $0^{\circ} \mathrm{C}$-day in the 2020s, 2050s and 2080s, respectively. Therefore, the need for heating can be eliminated for all applications except where strict comfort conditions need to be maintained. For this reason, further investigations on degree-days in this research focus only on cooling degree-days.

\subsubsection{Cooling degree-days}

Annual cooling degree-days at all investigated base temperatures tend to increase in future climates. Figure 6 shows the variations in the number of cooling degree-days in the four investigated climates at base
Table 1: Annual heating degree-days, $D_{\mathrm{h}, \mathrm{a}}$, in the present-day, 2020s, 2050s and 2080s.

\begin{tabular}{lrrrrrrr}
\hline Climate & \multicolumn{8}{c}{$\begin{array}{c}\text { Annual heating degree-days, } D_{\mathrm{h}, \mathrm{a}} \\
\left({ }^{\circ} \mathrm{C}-\text { day }\right)\end{array}$} \\
\cline { 2 - 8 } & \multicolumn{7}{c}{ Heating base temperature, $\theta_{\mathrm{b}, \mathrm{h}}$} \\
& 10 & 12 & 14 & 15.5 & 16 & 18 & 20 \\
\hline Present-day & 0 & 3 & 13 & 34 & 44 & 102 & 190 \\
$2020 \mathrm{~s}$ & 0 & 0 & 4 & 13 & 18 & 57 & 126 \\
$2050 \mathrm{~s}$ & 0 & 0 & 1 & 3 & 5 & 22 & 64 \\
$2080 \mathrm{~s}$ & 0 & 0 & 0 & 0 & 0 & 3 & 17 \\
\hline
\end{tabular}

temperatures: $10^{\circ} \mathrm{C}, 13^{\circ} \mathrm{C}, 16^{\circ} \mathrm{C}, 19^{\circ} \mathrm{C}, 22^{\circ} \mathrm{C}$ and $25^{\circ} \mathrm{C}$. At $\theta_{\mathrm{b}, \mathrm{c}}=10^{\circ} \mathrm{C}$, the ASHRAE reference base temperature for cooling [23], annual cooling degree-days, $D_{c, \text { a }}$ for the present-day, 2020s, 2050s and 2080s are $5946^{\circ} \mathrm{C}$-day, $6306^{\circ} \mathrm{C}$-day, $6797^{\circ} \mathrm{C}$-day and $7577^{\circ} \mathrm{C}$-day, respectively. At $\theta_{\mathrm{b}, \mathrm{c}}=15.5^{\circ} \mathrm{C}$, the UK reference base temperature [16], $D_{\mathrm{c}, \mathrm{a}}$ for the present-day, 2020s, 2050s and 2080s are $3911^{\circ} \mathrm{C}$-day, $4250{ }^{\circ} \mathrm{C}$-day, $4732^{\circ} \mathrm{C}$-day and $5697^{\circ} \mathrm{C}$ day, respectively. The magnitude and monthly variations of change in degree-days in different climates are discussed in the following sections.

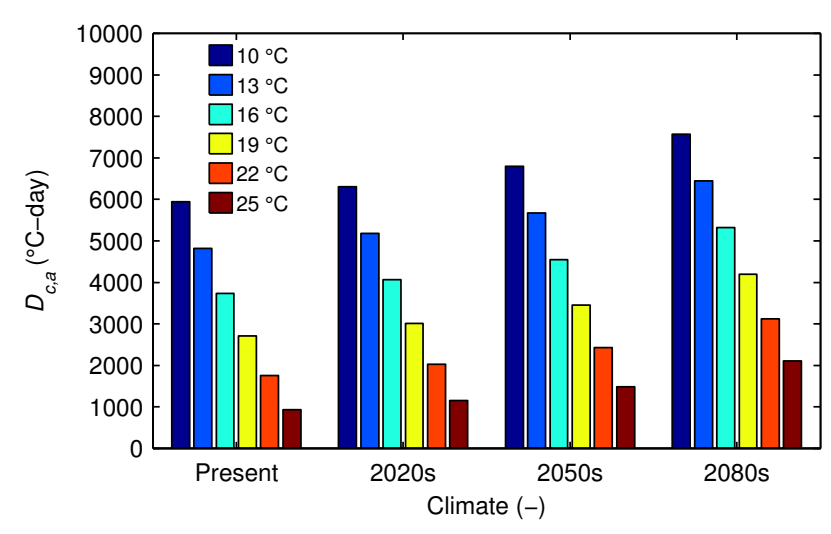

Figure 6: Annual cooling degree-days, $D_{\mathrm{c}, \mathrm{a}}$, at different cooling base temperature, $\theta_{\mathrm{b}, \mathrm{c}}$, in the present-day and future climates.

Monthly cooling degree-days, $D_{\mathrm{c}, \mathrm{m}}$, in the presentday, 2020s, 2050s and 2080s are given in Tables 2, 3, 4 and 5 , respectively. In the present-day, $D_{c, m}$ in $\mathrm{Au}-$ gust is the greatest at base temperatures between $10^{\circ} \mathrm{C}$ and $20^{\circ} \mathrm{C}$. At base temperatures between $21^{\circ} \mathrm{C}$ and $25^{\circ} \mathrm{C}$, $D_{\mathrm{c}, \mathrm{m}}$ in June is the greatest. In the 2020s, $D_{\mathrm{c}, \mathrm{m}}$ in August is the greatest at all base temperatures except $28^{\circ} \mathrm{C}$. In the 2050s, $D_{\mathrm{c}, \mathrm{m}}$ in August is the greatest at all base temperatures but in the 2080s, $D_{\mathrm{c}, \mathrm{m}}$ in April is the greatest at all base temperatures. The monthly variations are illustrated in Figure 7, which shows the flattening ten- 
dency of the curve between April and October in future climates. In the 2080s, monthly cooling degree-days are similar in magnitude between March and October, suggesting a consistently high demand for cooling.

\subsubsection{Change in cooling degree-days}

Changes in monthly cooling degree-days at different base temperatures in future climates from the baseline present-day climate is shown in Figure 8. Monthly variations in change are uneven and disparate at different base temperatures. Increases in monthly cooling degree-days in the 2020s are almost even across the months of the year but an uneven trend appears to emerge in the 2050s onwards. Monthly cooling degree-days in winter months increase more than the cooling degree-days in monsoon months, except October. Changes in cooling degree-days for winter months (November to March) are higher at low base temperatures (e.g., $\theta_{\mathrm{b}, \mathrm{c}}=10^{\circ} \mathrm{C}$ ) than those at high base temperatures (e.g., $\theta_{\mathrm{b}, \mathrm{c}}=25^{\circ} \mathrm{C}$ ). As winter gets warmer in future climates the occurrences of temperatures above low base temperatures increases.

Percentage changes in monthly cooling degree-days at different base temperatures, representing the magnitude of change in future climates against the baseline present-day climate, are illustrated in Figure 9. The magnitude of change in cooling degree-days are similar in shape to the magnitude of change in daily mean temperature in future climates (see Figure 4). Percentage changes in cooling degree-days at high base temperatures (e.g., $\theta_{\mathrm{b}, \mathrm{c}}=25^{\circ} \mathrm{C}$ ) are higher than those at low base temperatures (e.g., $\theta_{\mathrm{b}, \mathrm{c}}=10^{\circ} \mathrm{C}$ ). $D_{\mathrm{c}, \mathrm{m}}$ at higher base temperatures is low in winter months in the present-day; therefore, small changes in the value in future climates translates to large percentage changes; e.g., the percentage change in monthly cooling degree-days in January in the 2080s at $\theta_{\mathrm{b}, \mathrm{c}}=25^{\circ} \mathrm{C}$ is $925 \%$ but the actual change is only $37^{\circ} \mathrm{C}$-day $(41-4=37)$.

\subsection{Hot spells}

In addition to the risk of overheating (see Figure 5), the occurrence of hot spells will be prevalent in future climates, well beyond the months typically considered as hot. A hot spell has previously been defined as a period when the previous three or five days have had temperatures exceeding $25^{\circ} \mathrm{C}$ for more than three hours [30]. According to this definition, Dhaka experiences almost continuous hot spells throughout the year, except for a few days in January and December, even in the presentday climate. The severity (i.e., the differences between outdoor temperatures and the reference temperature) and the duration (i.e., the time this difference persists) of hot spells tend to increase in future climates, which will add further complexities in the energy efficient design and operation of a resilient built environment. Vulnerable groups of people such as babies, young children, elderly and people at-risk (e.g., people who are confined to bed or who has preexisting psychiatric illness) will be particularly affected by the excessive heat [41, 42].

\subsection{Building energy demand}

It is evident that energy use for maintaining comfort conditions in buildings in Dhaka will continue to grow under future climates. Heating degree-days and corresponding energy demand is very low in the present-day and can be eliminated altogether in the future. Cooling degree-days and corresponding energy demand, on the other hand, will continue to increase under future climates and likely to affect the already stressed energy infrastructure in the country. Most of the cooling energy demand may have to be met through electricity, a carbon intensive form of energy. This will have serious consequences for energy security as the existing electricity infrastructure in Bangladesh is deemed as inadequate even to meet present demand. Only $43 \%$ of the population is served by the grid and per capita electricity consumption in 2007 was $143.6 \mathrm{~kW} \cdot \mathrm{h}$, which was one of the lowest in the world [43]. Electricity consumption is likely to increase with the growth in gross domestic product (GDP) and income. Increasing demand for energy for comfort cooling is likely to exacerbate the situation. Unless significant investments are made in research and development on low carbon cooling solutions, the impact of increased temperatures on buildings is likely to affect the country's energy security and carbon emissions.

As cooling energy demand is proportional to cooling degree-days for the corresponding period, it can be asserted that cooling energy consumption in a building in Dhaka with a balance point temperature of $10^{\circ} \mathrm{C}$ will increase by $6 \%, 14 \%$ and $28 \%$ in the 2020s, 2050s and 2080s, respectively. Similarly, for buildings with a balance point temperature of $25^{\circ} \mathrm{C}$, cooling energy consumption will increase by $23 \%, 59 \%$ and $127 \%$ in the 2020s, 2050s and 2080s, respectively. Percentage changes in annual cooling degree-days; i.e., probable changes in cooling energy consumption, for base temperatures between $10^{\circ} \mathrm{C}$ and $25^{\circ} \mathrm{C}$ for future climates are given in Table 6.

\section{Adaptation of buildings to increased temperatures}

Environmental design of buildings needs to be of high quality to tackle the challenges of overheating and hot spells. Temperatures in a poorly designed building can be in excess of the outdoor temperatures during hot spells. It has been suggested that through proper use of thermal storage and solar shading, it might be possible to keep the building close to the daily mean temperature, or even lower, for the duration of hot spells [30]. In these strategies, higher air temperatures are offset by cooler mean radiant temperatures and enhanced 
Table 2: Monthly cooling degree-days, $D_{\mathrm{c}, \mathrm{m}}$, in the present-day.

\begin{tabular}{|c|c|c|c|c|c|c|c|c|c|c|c|c|c|c|c|c|}
\hline \multirow[t]{3}{*}{ Month } & \multicolumn{16}{|c|}{ Monthly cooling degree-days, $D_{\mathrm{c}, \mathrm{m}}\left({ }^{\circ} \mathrm{C}\right.$-day $)$} \\
\hline & \multicolumn{16}{|c|}{ Cooling base temperature, $\theta_{\mathrm{b}, \mathrm{c}}\left({ }^{\circ} \mathrm{C}\right)$} \\
\hline & 10 & 11 & 12 & 13 & 14 & 15 & 16 & 17 & 18 & 19 & 20 & 21 & 22 & 23 & 24 & 25 \\
\hline January & 265 & 235 & 206 & 178 & 152 & 128 & 107 & 89 & 72 & 57 & 44 & 32 & 22 & 14 & 8 & 4 \\
\hline February & 339 & 310 & 282 & 253 & 225 & 197 & 171 & 147 & 125 & 104 & 85 & 67 & 51 & 38 & 27 & 18 \\
\hline March & 513 & 481 & 449 & 417 & 385 & 353 & 321 & 289 & 258 & 227 & 197 & 168 & 140 & 115 & 92 & 72 \\
\hline April & 562 & 531 & 500 & 469 & 438 & 407 & 376 & 345 & 314 & 283 & 252 & 222 & 192 & 163 & 137 & 112 \\
\hline May & 578 & 546 & 514 & 482 & 450 & 418 & 386 & 354 & 322 & 290 & 258 & 226 & 195 & 164 & 136 & 108 \\
\hline Jun & 600 & 569 & 538 & 507 & 476 & 445 & 414 & 383 & 352 & 321 & 290 & 259 & 228 & 197 & 166 & 136 \\
\hline July & 589 & 557 & 525 & 493 & 461 & 429 & 397 & 365 & 333 & 301 & 269 & 237 & 205 & 173 & 141 & 109 \\
\hline August & 610 & 578 & 546 & 514 & 482 & 450 & 418 & 386 & 354 & 322 & 290 & 258 & 226 & 194 & 162 & 130 \\
\hline September & 578 & 547 & 516 & 485 & 454 & 423 & 392 & 361 & 330 & 299 & 268 & 237 & 206 & 175 & 145 & 114 \\
\hline October & 560 & 528 & 496 & 464 & 432 & 400 & 368 & 336 & 304 & 272 & 240 & 208 & 177 & 146 & 117 & 90 \\
\hline November & 431 & 400 & 369 & 338 & 307 & 276 & 245 & 214 & 184 & 155 & 127 & 101 & 79 & 60 & 44 & 31 \\
\hline December & 318 & 286 & 254 & 223 & 192 & 162 & 136 & 112 & 90 & 71 & 55 & 41 & 29 & 19 & 12 & 7 \\
\hline
\end{tabular}

Table 3: Monthly cooling degree-days, $D_{\mathrm{c}, \mathrm{m}}$, in the 2020s.

\begin{tabular}{|c|c|c|c|c|c|c|c|c|c|c|c|c|c|c|c|c|}
\hline \multirow[t]{3}{*}{ Month } & \multicolumn{16}{|c|}{ Monthly cooling degree-days, $D_{\mathrm{c}, \mathrm{m}}\left({ }^{\circ} \mathrm{C}\right.$-day $)$} \\
\hline & \multicolumn{16}{|c|}{ Cooling base temperature, $\theta_{\mathrm{b}, \mathrm{c}}\left({ }^{\circ} \mathrm{C}\right)$} \\
\hline & 10 & 11 & 12 & 13 & 14 & 15 & 16 & 17 & 18 & 19 & 20 & 21 & 22 & 23 & 24 & 25 \\
\hline January & 307 & 276 & 245 & 215 & 186 & 159 & 134 & 112 & 92 & 74 & 59 & 45 & 32 & 22 & 14 & 7 \\
\hline & 374 & 345 & 316 & 287 & 258 & 230 & 202 & 175 & 149 & 126 & 105 & 85 & 67 & 51 & 37 & 25 \\
\hline Marc & 549 & 517 & 485 & 453 & 421 & 389 & 357 & 325 & 294 & 262 & 231 & 201 & 172 & 144 & 119 & 96 \\
\hline April & 591 & 560 & 529 & 498 & 467 & 436 & 405 & 374 & 343 & 312 & 281 & 250 & 219 & 189 & 160 & 133 \\
\hline May & 602 & 570 & 538 & 506 & 474 & 442 & 410 & 378 & 346 & 314 & 282 & 250 & 218 & 186 & 156 & 128 \\
\hline June & 619 & 588 & 557 & 526 & 495 & 464 & 433 & 402 & 371 & 340 & 309 & 278 & 247 & 216 & 185 & 154 \\
\hline July & 609 & 577 & 545 & 513 & 481 & 449 & 417 & 385 & 353 & 321 & 289 & 257 & 225 & 193 & 161 & 129 \\
\hline Augu & 638 & 606 & 574 & 542 & 510 & 478 & 446 & 414 & 382 & 350 & 318 & 286 & 254 & 222 & 190 & 158 \\
\hline Septe & 606 & 575 & 544 & 513 & 482 & 45 & 420 & 389 & 358 & 327 & 296 & 265 & 234 & 204 & 173 & 142 \\
\hline Octob & 595 & 563 & 531 & 499 & 467 & 435 & 403 & 371 & 339 & 307 & 275 & 243 & 211 & 179 & 149 & 119 \\
\hline Nove & 464 & 433 & 402 & 371 & 340 & 309 & 278 & 247 & 216 & 186 & 156 & 128 & 102 & 79 & 60 & 44 \\
\hline December & 350 & 318 & 286 & 254 & 223 & 191 & 162 & 135 & 111 & 90 & 71 & 54 & 40 & 28 & 18 & 11 \\
\hline
\end{tabular}

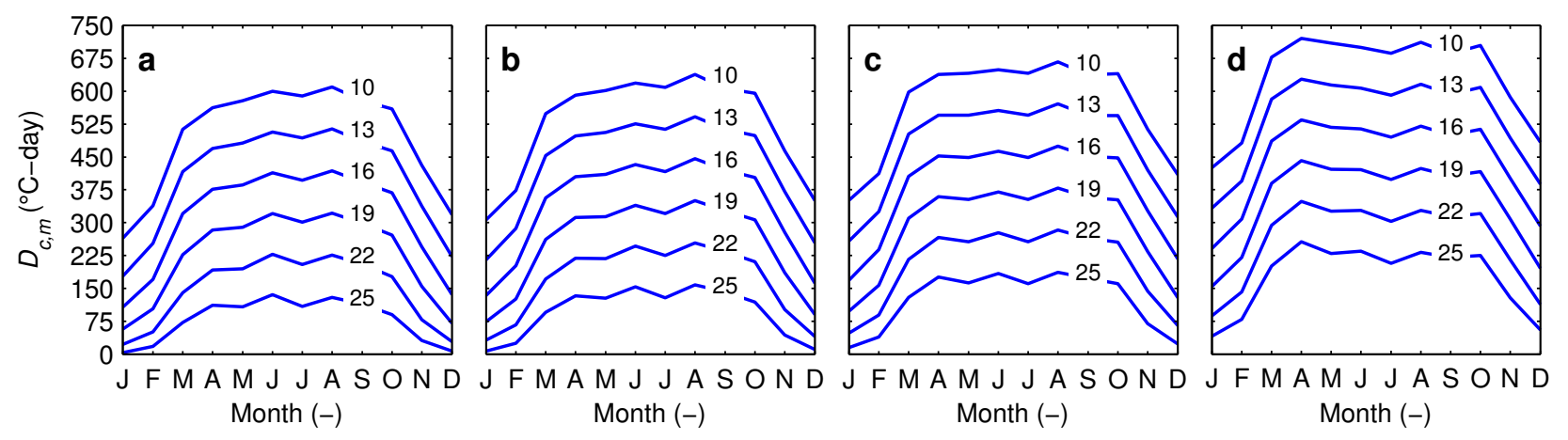

Figure 7: Monthly cooling degree-days at different cooling base temperature, $\theta_{\mathrm{b}, \mathrm{c}}$ in different climates: (a) Presentday, (b) 2020s, (c) 2050s and (d) 2080s. 
Table 4: Monthly cooling degree-days, $D_{\mathrm{c}, \mathrm{m}}$, in the 2050s.

\begin{tabular}{|c|c|c|c|c|c|c|c|c|c|c|c|c|c|c|c|c|}
\hline \multirow[t]{3}{*}{ Month } & \multicolumn{16}{|c|}{ Monthly cooling degree-days, $D_{\mathrm{c}, \mathrm{m}}\left({ }^{\circ} \mathrm{C}\right.$-day $)$} \\
\hline & \multicolumn{16}{|c|}{ Cooling base temperature, $\theta_{\mathrm{b}, \mathrm{c}}\left({ }^{\circ} \mathrm{C}\right)$} \\
\hline & 10 & 11 & 12 & 13 & 14 & 15 & 16 & 17 & 18 & 19 & 20 & 21 & 22 & 23 & 24 & 25 \\
\hline January & 351 & 320 & 289 & 258 & 227 & 198 & 169 & 143 & 119 & 98 & 79 & 63 & 48 & 35 & 24 & 15 \\
\hline February & 412 & 383 & 354 & 325 & 296 & 268 & 239 & 210 & 183 & 157 & 132 & 110 & 89 & 71 & 53 & 39 \\
\hline March & 598 & 566 & 534 & 502 & 470 & 438 & 406 & 374 & 342 & 310 & 278 & 247 & 216 & 186 & 157 & 130 \\
\hline April & 638 & 607 & 576 & 545 & 514 & 483 & 452 & 421 & 390 & 359 & 328 & 297 & 266 & 236 & 205 & 176 \\
\hline May & 641 & 609 & 577 & 545 & 513 & 481 & 449 & 417 & 385 & 353 & 321 & 289 & 257 & 225 & 194 & 163 \\
\hline $\mathrm{Ju}$ & 649 & 618 & 587 & 556 & 525 & 494 & 463 & 432 & 401 & 370 & 339 & 308 & 277 & 246 & 215 & 184 \\
\hline July & 641 & 609 & 577 & 545 & 513 & 481 & 449 & 417 & 385 & 353 & 321 & 289 & 257 & 225 & 193 & 161 \\
\hline August & 667 & 635 & 603 & 571 & 539 & 507 & 475 & 443 & 411 & 379 & 347 & 315 & 283 & 251 & 219 & 187 \\
\hline September & 637 & 606 & 575 & 544 & 513 & 482 & 451 & 420 & 389 & 358 & 327 & 296 & 265 & 234 & 203 & 173 \\
\hline October & 640 & 608 & 576 & 544 & 512 & 480 & 448 & 416 & 384 & 352 & 320 & 288 & 256 & 224 & 192 & 161 \\
\hline November & 513 & 482 & 451 & 420 & 389 & 358 & 327 & 296 & 265 & 234 & 203 & 173 & 144 & 117 & 92 & 70 \\
\hline December & 409 & 377 & 345 & 313 & 281 & 249 & 217 & 186 & 156 & 129 & 105 & 83 & 65 & 48 & 35 & 23 \\
\hline
\end{tabular}

Table 5: Monthly cooling degree-days, $D_{\mathrm{c}, \mathrm{m}}$, in the 2080s.

\begin{tabular}{|c|c|c|c|c|c|c|c|c|c|c|c|c|c|c|c|c|}
\hline \multirow[t]{3}{*}{ Month } & \multicolumn{16}{|c|}{ Monthly cooling degree-days, $D_{\mathrm{c}, \mathrm{m}}\left({ }^{\circ} \mathrm{C}\right.$-day $)$} \\
\hline & \multirow{2}{*}{\multicolumn{16}{|c|}{ Cooling base temperature, $\theta_{\mathrm{b}, \mathrm{c}}\left({ }^{\circ} \mathrm{C}\right)$}} \\
\hline & 10 & & & & & & & & & & & & & & & 25 \\
\hline Janua & 426 & 395 & 364 & 333 & 302 & 271 & 241 & 210 & 181 & 154 & 129 & 107 & 87 & 70 & 54 & 41 \\
\hline Febr & 482 & 453 & 424 & 395 & 366 & 337 & 308 & 279 & 250 & 221 & 194 & 167 & 142 & 120 & 99 & 79 \\
\hline March & 678 & 646 & 614 & 582 & 550 & 518 & 486 & 454 & 422 & 390 & 358 & 326 & 294 & 263 & 232 & 201 \\
\hline April & 721 & 690 & 659 & 628 & 597 & 566 & 535 & 504 & 473 & 442 & 411 & 380 & 349 & 318 & 287 & 256 \\
\hline May & 710 & 678 & 646 & 614 & 582 & 550 & 518 & 486 & 454 & 422 & 390 & 358 & 326 & 294 & 262 & 230 \\
\hline June & 700 & 669 & 638 & 607 & 576 & 545 & 514 & 483 & 452 & 421 & 390 & 359 & 328 & 297 & 266 & 235 \\
\hline & 687 & 655 & 623 & 591 & 559 & 527 & 495 & 463 & 431 & 399 & 367 & 335 & 303 & 271 & 239 & 207 \\
\hline Augus & 712 & 680 & 648 & 616 & 584 & 552 & 520 & 488 & 456 & 424 & 392 & 360 & 328 & 296 & 264 & 232 \\
\hline Septe & 686 & 655 & 624 & 593 & 562 & 531 & 500 & 469 & 438 & 407 & 376 & 345 & 314 & 283 & 252 & 221 \\
\hline Octob & 705 & 673 & 641 & 609 & 577 & 545 & 513 & 481 & 449 & 417 & 385 & 353 & 321 & 289 & 257 & 225 \\
\hline November & 587 & 556 & 525 & 494 & 463 & 432 & 401 & 370 & 339 & 308 & 277 & 246 & 215 & 185 & 156 & 128 \\
\hline December & 484 & 452 & 420 & 388 & 356 & 324 & 292 & 260 & 228 & 196 & 166 & 138 & 113 & 91 & 72 & 55 \\
\hline
\end{tabular}

Table 6: Percentage change in annual cooling degree-days at different base temperature, $\theta_{\mathrm{b}, \mathrm{c}}$, in the 2020s, 2050s and 2080s from the baseline present-day climate.

\begin{tabular}{|c|c|c|c|c|c|c|c|c|c|c|c|c|c|c|c|c|}
\hline \multirow[t]{3}{*}{ Climate } & \multirow{2}{*}{\multicolumn{16}{|c|}{$\begin{array}{c}\text { Change in annual cooling degree-days, } D_{\mathrm{c}, \mathrm{a}}(\%) \\
\text { Cooling base temperature, } \theta_{\mathrm{b}, \mathrm{c}}\left({ }^{\circ} \mathrm{C}\right)\end{array}$}} \\
\hline & & & & & & & & & & & & & & & & \\
\hline & 10 & 11 & 12 & 13 & 14 & 15 & 16 & 17 & 18 & 19 & 20 & 21 & 22 & 23 & 24 & 25 \\
\hline $2020 \mathrm{~s}$ & 6 & 6 & 7 & 7 & 8 & 8 & 9 & 10 & 10 & 11 & 13 & 14 & 15 & 17 & 20 & 23 \\
\hline $2050 \mathrm{~s}$ & 14 & 15 & 16 & 18 & 19 & 20 & 22 & 23 & 25 & 28 & 31 & 34 & 38 & 44 & 50 & 59 \\
\hline $2080 \mathrm{~s}$ & 28 & 29 & 31 & 34 & 36 & 39 & 43 & 46 & 51 & 55 & 61 & 69 & 78 & 90 & 106 & 127 \\
\hline
\end{tabular}

air movement [38]. However, the small diurnal variation; i.e., the difference between daily maximum and minimum temperatures (see Figure 3), during summer and monsoon seasons, may restrict the effectiveness of such strategies.

It will be challenging to design buildings for natural or hybrid ventilation in Dhaka. Cooling loads comprising solar and internal heat gains will play an important 

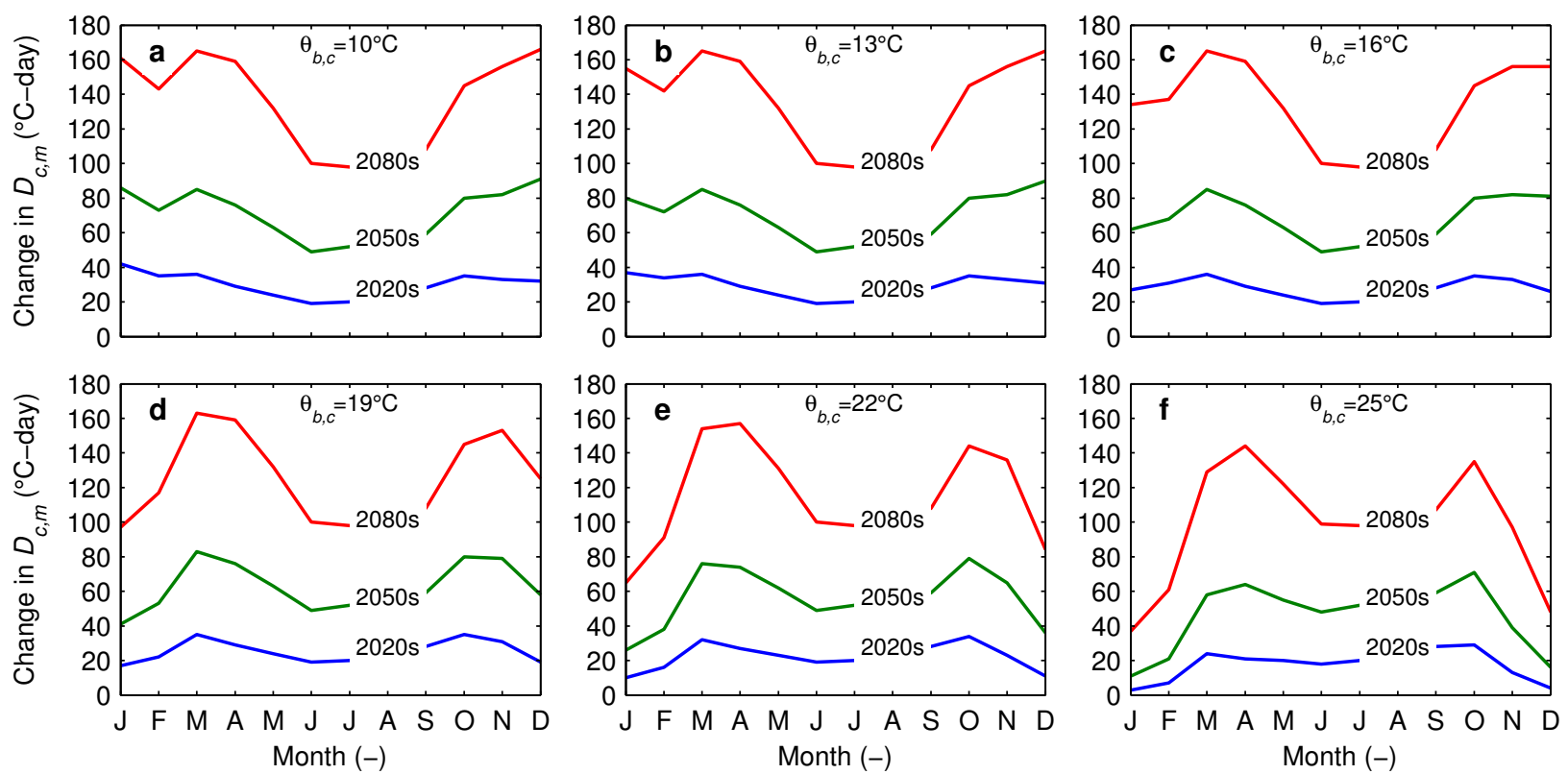

Figure 8: Change in monthly cooling degree-days in future climates from the baseline present-day climate at different cooling base temperature, $\theta_{\mathrm{b}, \mathrm{c}}$ : (a) $10^{\circ} \mathrm{C}$, (b) $13^{\circ} \mathrm{C}$, (c) $16^{\circ} \mathrm{C}$, (d) $19^{\circ} \mathrm{C}$, (e) $22^{\circ} \mathrm{C}$ and (f) $25^{\circ} \mathrm{C}$.
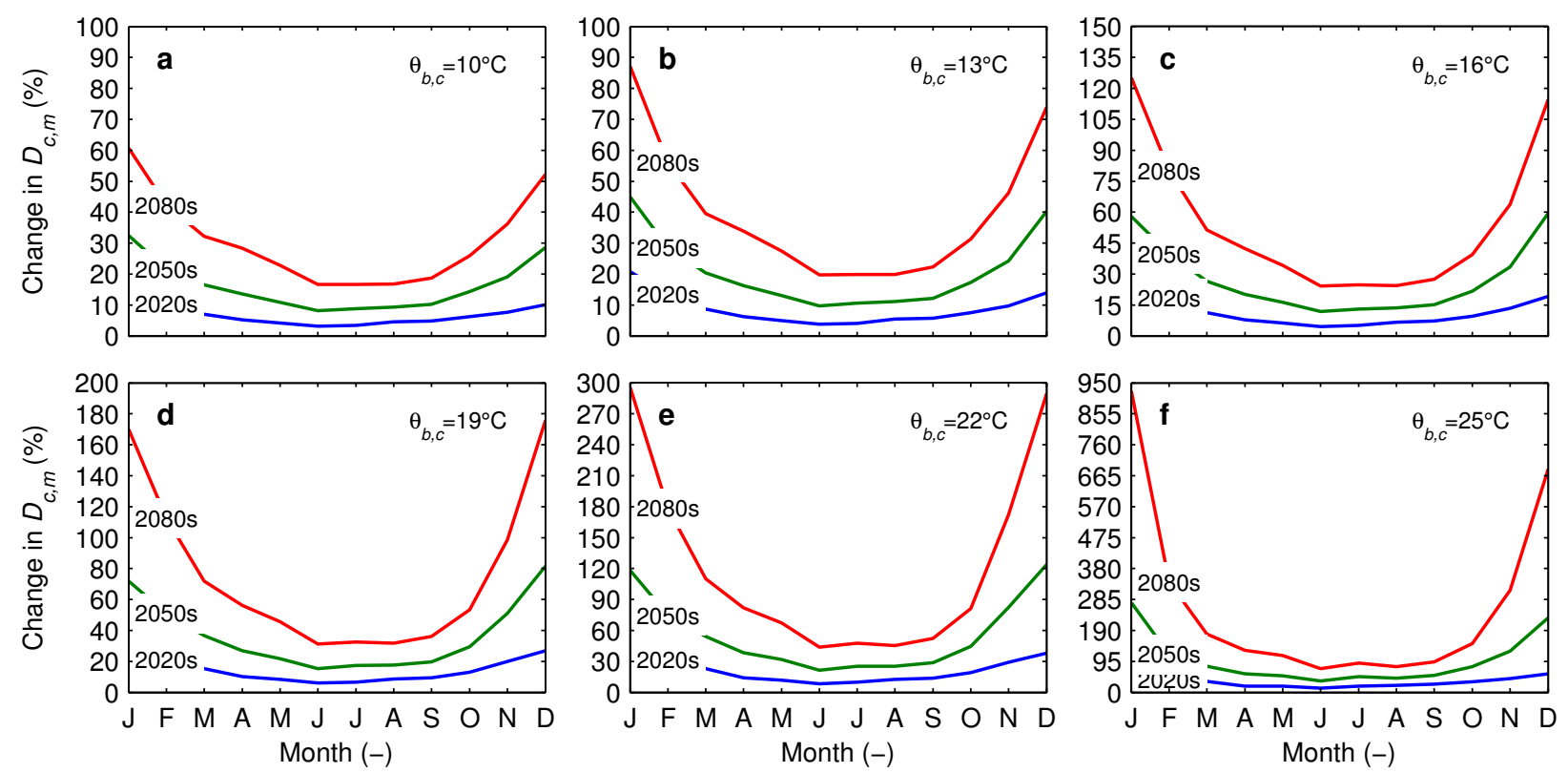

Figure 9: Percentage change in cooling degree-days in future climates for various base temperatures, $\theta_{\mathrm{b}, \mathrm{c}}$ : (a) $10^{\circ} \mathrm{C}$, (b) $13^{\circ} \mathrm{C}$, (c) $16^{\circ} \mathrm{C}$, (d) $19^{\circ} \mathrm{C}$, (e) $22^{\circ} \mathrm{C}$ and (f) $25^{\circ} \mathrm{C}$.

role in the ability of a building to be naturally ventilated or to be adapted to the projected increases in temperature. In the UK, natural ventilation systems are said to be able to meet total heat loads (combined solar and internal heat gains) averaged over the day of around 30 $40 \mathrm{~W} \cdot \mathrm{m}^{-2}$ [38]. This threshold of total loads will be even lower for Dhaka because of the prevalence of high temperatures and poor thermal performance of building en- velopes. Careful design of the building fabric [44] including the size and orientation of windows; thermal insulation [45] and solar shading [46] may assist in reducing solar heat gain. Internal heat gains from people, equipment and lighting can be designed to avoid coincident solar and internal gains. It has been suggested that natural ventilation systems become ineffective if average coincident internal gains over the day exceed about 15- 
$20 \mathrm{~W} \cdot \mathrm{m}^{-2}$ [47]. The minimization of the coincidence of the gains will determine how effective the strategies for the control of gains are; e.g., the responsiveness of the artificial lighting system to the availability of daylight. The location of heat-emitting business equipment in a space will be as important as the specification of their energy efficiency.

As outdoor temperatures will be higher than indoor zone setpoint temperature for most of the times in a year, pre-cooling of the air could be desirable at least for the hotter months of the year. Due to high solar resource availability $\left(4.73 \mathrm{kWh} \cdot \mathrm{m}^{-2} \cdot \mathrm{day}^{-1}\right.$ on average in Dhaka [48]), solar absorption cooling [49, 50] could be a viable alternative to energy intensive refrigeration based cooling systems. However, research needs to be carried out on the performance of such systems in meeting the demand and whether the systems need to be co-located with significant heat sources (e.g., waste heat from industrial processes) or coolth storage to cope with the lack of solar radiation during the night. Among other solutions, thermo-active building systems (TABS) that employ building structure (wall, floor and ceiling) and its thermal storage capacity for building energy management [51] can offer desired energy efficiency while providing required thermal comfort.

In order to direct building activities, both new-build and retrofit constructions, in a sustainable direction, building regulations need to be updated to incorporate measures to adapt to the projected increases in temperature in future climates. Updates to the existing building regulations [52] need to be evidence based and could benefit from the developments and research $[53,54]$ in other countries.

\section{Conclusion}

Present-day statistically averaged weather data for Dhaka, Bangladesh is morphed with the projections for medium-high emissions scenario (IPCC A2 storyline) from the IPCC HadCM3 climate model to generate future hourly time series of temperature in the 2020s, 2050s and 2080s. Corresponding heating and cooling degree-days at different base temperatures for the baseline present-day and future climates are calculated from the time series. The distribution of temperature shifts to the right under future climates; i.e., higher temperatures occur more than lower temperatures, which is indicative of the overall warming of the climate. The increase in temperature is likely to result in increased occurrences of building overheating; e.g., temperatures above $28^{\circ} \mathrm{C}$ occur for about $71.9 \%$ of the time of the year in the 2080s, compared to $31.0 \%$ in the present-day. Continuous hot spell is likely to be a common feature in future climates. The combination of overheating and the increased occurrence of hot spells will be a challenge for energy efficient and low carbon building design and operation.
Heating degree-days are traditionally low in Dhaka due to the prevalence of high temperatures throughout the year. Heating degree-days continue to decrease in future climates. On the other hand, cooling degreedays continue to increase. However, there exists an uneven variation of monthly cooling degree-days at different base temperatures. Percentage changes in cooling degree days during winter months are consistently higher at all base temperatures than those of the summer and monsoon months. Corresponding cooling energy demand increases in all future climates.

The thermal performance of the majority of buildings in Dhaka is poor; e.g., single glazed windows without adequate solar shading. Hence solar heat gains are in excess of what can be efficiently tackled by natural or hybrid ventilation systems. The projected increases in temperature are likely to exacerbate the situation. As buildings have a typical lifespan of 50 to 100 years, prompt actions to regulate the environmental performance of buildings are necessary to enhance the resilience of Dhaka's buildings to climate change.

\section{References}

[1] S. Huq, Climate change and Bangladesh, Science 294 (5547) (2001) 1617.

[2] EIA, International energy annual 2006, http://www.eia.doe.gov/iea/ (2008).

[3] S. Solomon, D. Qin, M. Manning, M. Marquis, K. Aveyrt, M. M. B. Tignor, J. Henry LeRoy Miller, Z. Chen (Eds.), Climate Change 2007: The Physical Science Basis: Contribution of Working Group I to the Fourth Assessment Report of the Intergovernmental Panel on Climate Change, Cambridge University Press, New York, NY, 2007.

[4] S. Huq, J. Ayers, Climate Change Impacts and Responses in Bangladesh, European Parliament, Brussels, Belgium, 2008.

[5] S. Ramamasy, S. Baas, Climate variability and change: adaptation to drought in Bangladesh, Food and Agriculture Organization of the United Nations, Rome, Italy, 2007.

[6] MoEF, Bangladesh climate change strategy and action plan 2008, Ministry of Environment and Forests, Government of the People's Republic of Bangladesh, Dhaka, Bangladesh, 2008.

[7] ADB, People's Republic of Bangladesh: Supporting Implementation of the Bangladesh Climate Change Strategy and Action Plan, Asian Development Bank, Mandaluyong, Philippines, 2009.

[8] WBCSD, Energy efficiency in buildings: Transforming the market, World Business Council for Sustainable Development, Geneva, Switzerland, 2009.

[9] IPCC, Summary for policymakers, in: Climate Change 2007: Synthesis Report: Fourth Assessment Report of the Intergovernmental Panel on Climate Change, Cambridge University Press, New York, NY, 2007, pp. 1-22.

[10] M. Gawith, R. Street, R. Westaway, A. Steynor, Application of the UKCIP02 climate change scenarios: Reflections and lessons learnt, Global Environmental Change 19 (1) (2009) 113-121.

[11] BBS, Statistical pocket book, Bangladesh Bureau of Statistics, Dhaka, Bangladesh, 2008.

[12] WB, Dhaka: Improving Living Conditions for the Urban Poor, The World Bank, Dhaka, Bangladesh, 2007.

[13] Z. F. Ali, Comfort with courtyards in dhaka apartments, BRAC University Journal 4 (2) (2007) 1-6.

[14] M. Kottek, J. Grieser, C. Beck, B. Rudolf, F. Rubel, World map of the Koppen-Geiger climate classification updated, Meteorologische Zeitschrift 15 (3) (2006) 259-263. 
[15] NASA, Visible earth: A catalog of nasa images and animations of our home planet, http://visibleearth.nasa.gov/ (2011).

[16] CIBSE, Degree-days: theory and application, TM41, Chartered Institution of Building Services Engineers, London, United Kingdom, 2006.

[17] M. Kadioğlu, Z. Şen, L. Gültekin, Variations and trends in turkish seasonal heating and cooling Degree-Days, Climatic Change 49 (1) (2001) 209-223.

[18] A. R. Day, T. G. Karayiannis, A new degree-day model for estimating energy demand in buildings, Building Services Engineering Research and Technology 20 (4) (1999) 173 -178.

[19] A. R. Day, An improved use of cooling degree-days for analysing chiller energy consumption in buildings, Building Services Engineering Research and Technology 26 (2) (2005) 115-127.

[20] K. Papakostas, T. Mavromatis, N. Kyriakis, Impact of the ambient temperature rise on the energy consumption for heating and cooling in residential buildings of Greece, Renewable Energy 35 (7) (2010) 1376-1379.

[21] H. Sarak, A. Satman, The degree-day method to estimate the residential heating natural gas consumption in Turkey: a case study, Energy 28 (9) (2003) 929-939.

[22] A. Ucar, F. Balo, Determination of the energy savings and the optimum insulation thickness in the four different insulated exterior walls, Renewable Energy 35 (1) (2010) 88-94.

[23] ASHRAE, ASHRAE Handbook: Fundamentals, American Society of Heating, Refrigerating and Air-Conditioning Engineers, Atlanta, GA, 2009.

[24] R. L. Layberry, Improvements to the meteorological office equations in the computation of degree days, Building Services Engineering Research and Technology 30 (4) (2009) 357 -362.

[25] E. R. Hitchin, Estimating monthly degree-days, Building Services Engineering Research and Technology 4 (4) (1983) 159-162.

[26] R. L. Layberry, Degree days for building energy management presentation of a new data set, Building Services Engineering Research and Technology 29 (3) (2008) $273-282$.

[27] A. R. Day, I. Knight, G. Dunn, R. Gaddas, Improved methods for evaluating base temperature for use in building energy performance lines, Building Services Engineering Research and Technology 24 (4) (2003) $221-228$.

[28] M. Collins, S. F. B. Tett, C. Cooper, The internal climate variability of HadCM3, a version of the hadley centre coupled model without flux adjustments, Climate Dynamics 17 (1) (2001) 61-81-81.

[29] S. E. Belcher, J. N. Hacker, D. S. Powell, Constructing design weather data for future climates, Building Services Engineering Research and Technology 26 (1) (2005) 49-61.

[30] CIBSE, Climate change and the indoor environment: impacts and adaptation, TM36, Chartered Institution of Building Services Engineers, London, United Kingdom, 2005.

[31] M. F. Jentsch, A. S. Bahaj, P. A. B. James, Climate change future proofing of buildings-Generation and assessment of building simulation weather files, Energy and Buildings 40 (12) (2008) 2148-2168.

[32] CIBSE, Use of climate change scenarios for building simulation: the CIBSE future weather years, TM48, Chartered Institution of Building Services Engineers, London, United Kingdom, 2009.

[33] N. Nakicenovic, R. Swart (Eds.), IPCC special report on emissions scenarios: A special report of working group III of the intergovernmental panel on climate change, Cambridge University Press, Cambridge, UK, 2000.

[34] IPCC, IPCC data distribution centre, http://www.ipcc-data.org/ (2010).

[35] SWERA, Data for solar and wind renewable energy, http://swera.unep.net/ (2010).

[36] D. B. Crawley, Which weather data should you use for energy simulations of commercial buildings?, ASHRAE Transactions 104 (2) (1998) 498-515.

[37] K. Skeiker, Comparison of methodologies for TMY generation using 10 years data for Damascus, Syria, Energy Conversion and Management 48 (7) (2007) 2090-2102.

[38] CIBSE, Natural ventilation in non-domestic buildings, AM10, Chartered Institution of Building Services Engineers, London,
United Kingdom, 2005

[39] H. Eppel, K. J. Lomas, Comparison of alternative criteria for assessing overheating in buildings, Tech. Rep. BRE Support Contract Report 12, Leicester Polytechnic (De Montfort University), Leicester, UK (1992).

[40] F. H. Mallick, Thermal comfort and building design in the tropical climates, Energy and Buildings 23 (3) (1996) 161-167.

[41] S. Hajat, M. O'Connor, T. Kosatsky, Health effects of hot weather: from awareness of risk factors to effective health protection, The Lancet 375 (9717) (2010) 856-863.

[42] A. J. McMichael, R. E. Woodruff, S. Hales, Climate change and human health: present and future risks, The Lancet 367 (9513) (2006) 859-869.

[43] S. A. Chowdhury, M. Mourshed, S. M. R. Kabir, M. Islam, T. Morshed, M. R. Khan, M. N. Patwary, Technical appraisal of solar home systems in Bangladesh: A field investigation, Renewable Energy 36 (2) (2011) 772-778.

[44] L. Yang, J. C. Lam, C. L. Tsang, Energy performance of building envelopes in different climate zones in China, Applied Energy 85 (9) (2008) 800-817.

[45] M. A. Aktacir, O. Büyükalaca, T. YIlmaz, A case study for influence of building thermal insulation on cooling load and airconditioning system in the hot and humid regions, Applied Energy 87 (2) (2010) 599-607.

[46] A. I. Palmero-Marrero, A. C. Oliveira, Effect of louver shading devices on building energy requirements, Applied Energy 87 (6) (2010) 2040-2049.

[47] CIBSE, Design for improved solar shading control, TM37, Chartered Institution of Building Services Engineers, London, United Kingdom, 2006.

[48] M. A. H. Mondal, M. Denich, Assessment of renewable energy resources potential for electricity generation in Bangladesh, Renewable and Sustainable Energy Reviews 14 (8) (2010) 2401-2413.

[49] F. Calise, A. Palombo, L. Vanoli, Maximization of primary energy savings of solar heating and cooling systems by transient simulations and computer design of experiments, Applied Energy 87 (2) (2010) 524-540.

[50] T. Mateus, A. C. Oliveira, Energy and economic analysis of an integrated solar absorption cooling and heating system in different building types and climates, Applied Energy 86 (6) (2009) 949957.

[51] D. E. Kalz, J. Wienold, M. Fischer, D. Cali, Novel heating and cooling concept employing rainwater cisterns and thermo-active building systems for a residential building, Applied Energy 87 (2) (2010) 650-660.

[52] MoW, Bangladesh National Building Code (BNBC), Ministry of Works, Dhaka, Bangladesh, 2006.

[53] R. Fayaz, B. M. Kari, Comparison of energy conservation building codes of Iran, Turkey, Germany, China, ISO 9164 and EN 832, Applied Energy 86 (10) (2009) 1949-1955.

[54] H. Radhi, A. Eltrapolsi, S. Sharples, Will energy regulations in the gulf states make buildings more comfortable - a scoping study of residential buildings, Applied Energy 86 (12) (2009) 2531-2539. 